\title{
UCLA RADIOCARBON DATES III
}

\author{
G. J. FERGUSSON and W. F. LIBBY \\ Institute of Geophysics, University of California, Los Angeles 24, California
}

The measurements reported in this list have been made in the Isotope Laboratory of the Institute of Geophysics during 1963 and are a continuation of the work reported previously (UCLA I and UCLA II). The same counting procedure $-\mathrm{CO}_{2}$ proportional counting at $1 \mathrm{~atm}$ pressure in a $7.5 \mathrm{~L}$ counter with three energy channels - continues in use. No barometric effect on the background has been observed, presumably because of the combination of fairly constant barometric pressure in this area and the location of the equipment on the ground floor of a five storey building. Dates continue to be calculated on the basis of a $\mathrm{C}^{14}$ half life of $5568 \mathrm{yr}$ according to the decision of the 1962 Cambridge Conference (Godwin, 1962). The modern standard has been taken as $95 \%$ of NBS oxalic acid for all organic samples, while for carbonate material such as shells and tufa, dates have been computed on the basis of estimates of the corresponding contemporary $\mathrm{C}^{14}$ activity (Broecker and Walton, 1959) as indicated in the description accompanying the results.

\section{ACKNOWLEDGMENTS}

We are indebted to the National Science Foundation for Grant G-14287 for financial support for this work, and also acknowledge the excellent assistance of Ervin Taylor and Carleton Hoel with laboratory work.

\section{SAMPLE DESCRIPTIONS}

\section{A. Tule Springs, Nevada}

Tule Springs, Clark County, Nevada ( $36^{\circ} 19^{\prime} \mathrm{N}$ Lat, $155^{\circ} 09^{\prime} \mathrm{W}$ Long) lies approx. $12 \mathrm{mi} \mathrm{NW}$ of Las Vegas, at an alt of $2307 \mathrm{ft}$. The first investigations in this locality were in 1933 by the Am. Mus. of Nat. History. Subsequently, this general area has been excavated by three expeditions from the Southwest Museum, Los Angeles, California (Harrington and Simpson, 1961). Radiocarbon dates from the site of $>23,000 \mathrm{yr}$ (C-914, Chicago V) and $>28,000 \mathrm{yr}$ (L-533B, Lamont VII) on materials supposedly associated with evidence of human occupation provided the stimulus for a systematic excavation. From October 1962 to February 1963 the Nevada State Mus., assisted by a National Science Foundation grant, made an extensive excavation of the site. The major financial support and planning assistance were provided by H. C. Smith and the Isotope Foundation of Los Angeles. Because of the interdisciplinary nature of the project, an Advisory Committee provided assistance at all stages. These people were H. C. Smith, J. D. Clark, E. W. Haury, R. F. Heizer, A. D. Krieger, W. F. Libby, C. Longwell and H. M. Worthington. Close collaboration between field work and the dating laboratory was maintained by R. E. Taylor of this laboratory who spent part of each week on the site. Dates presented were all obtained during this excavation and all samples were submitted by Richard Shutler, Jr., Nevada State Mus., who directed the excavations. More detailed reports on the geology and archaeology are in preparation. 
The following list has been divided into three sections: two relate to archaeological and geological material from two separate areas, Tule Springs Site and Corn Creek Site, while the third consists of samples from springs that help in the interpretation of the geological history.

\section{Tule Springs Site}

The main Tule Springs site area, about $2500 \mathrm{ft}$ by $700 \mathrm{ft}$, lies along the edge of the Vegas Wash. Erosion of the wash channel had exposed fossil material and therefore the main excavation was centered in this area. Most of the dates reported in this section are for samples from the main site area, the other samples being from sites about 2 to 3 mi along the wash channel from the main site.

Heavy earth moving machinery was used to dig several trenches, some $30 \mathrm{ft}$ deep and several thousand $\mathrm{ft}$ in length, across the site. The cross-sections displayed by these trenches were of immense value in unraveling the geological sequence in the site area.

The geological history of this site is a complex one, with repeated deposition of alluvium, formation of lakes and cutting of stream channels. Spring activity has also occurred at various periods and is related to faulting.

For convenience, dates in this section are grouped according to five main time periods. These are spring-pond phase, lacustrine phase, early post-playa phase, middle post-playa phase and proto historic alluvial phase.

Some tufa samples, deposited by springs, have been dated in this series in an attempt to set approximate ages when no organic carbon samples were available. For these tufa samples $2500 \mathrm{yr}$ (corresponds to $73 \%$ of contemporary $\mathrm{C}^{14}$ activity) were subtracted from the age computed on the basis of $0.95 \mathrm{NBS}$ oxalic acid and the error was increased to $\pm 1000 \mathrm{yr}$ to allow for the uncertainty in $\mathrm{C}^{14}$ activity at zero age.

\section{Tule Springs series, spring-pond phase}

One of the features that was very apparent in the cross sections was the so-called "green pond" unit. These green sediments, related to ancient springs, can be seen throughout most of the area of excavations. All of the following dates are from spring-laid sediments, containing a vertebrate assemblage but no evidence of human habitation.

\section{UCLA-501. Tule Springs}

$$
\begin{aligned}
& \mathbf{2 6 , 0 0 0} \pm 900 \\
& \mathbf{2 4 , 0 5 0} \text { в.C. }
\end{aligned}
$$

Plant remains in pale "green pond" stratum, associated with animal bones, some of which were exposed as a result of erosion. Sample from upper portion of bone assemblage, which was by far the largest found on the site. Southwest Museum Area 1, Site A, from which portions of samples C.-914 and L-533B taken. Coll. 1962 by R. E. Taylor.

UCLA-517. Tule Springs

Black plant remains from middle of bone assemblage (see UCLA-501) which was 4 to $5 \mathrm{ft}$ thick. Coll. 1962 by J. Mawby, N. Noble and B. Orlins. 
UCLA-502. Tule Springs

Plant remains from contact zone, ca. 8 in. thick, between loose silt with rolled caliche gravel and hard jointed siltstone. In "green pond" sediments, 16 in. below surface. Approx. $20 \mathrm{ft} \mathrm{NW}$ of and $3.5 \mathrm{ft}$ above UCLA-501 in absolute elevation. Coll. 1962 by R. E. Taylor.

UCLA-511. Tule Springs

$>32,000$

Plant remains in pale greenish white siltstone of early pond phase, 14 to 20 in. below surface. Bone fragments, a horse tooth and a bone too (?) found in close proximity. Approx. $20 \mathrm{ft} \mathrm{E}$ of and $1.3 \mathrm{ft}$ above UCLA -501 in absolute elevation. Coll. 1962 by P. Williams and R. E. Taylor.

UCLA-528. Tule Springs

Black plant remains from an apparent spring feeder at top of "green pond" unit in base of gray clay, 4 to $5 \mathrm{ft}$ below surface. Should provide minimum age of pond phase. Approx. $50 \mathrm{ft} \mathrm{S}$ of and $2 \mathrm{ft}$ above UCLA-501 in absolute elevation. Coll. 1963 by P. Williams.

UCLA-506. Tule Springs

Carbonaceous material in pale greenish white silt unit, limonite stained, associated with bone fragments. Expected to be "green pond" age. $2.3 \mathrm{ft}$ below surface. Approx. $300 \mathrm{ft} \mathrm{E}$ of and $4.3 \mathrm{ft}$ above UCLA-501 in absolute elevation. Coll. 1962 by W. Stein.

UCLA-523. Tule Springs

Wood from outcrop of "green pond" unit, associated with broken mammal bones, 6 in. to $2 \mathrm{ft}$ below surface. No evidence of human occupation. Approx. $600 \mathrm{ft}$ E of UCLA-501. Coll. 1962 by W. Stein.

UCLA-547. Tule Springs

Snail shells from a secondary channel fill in "green pond" unit. Same stratum as UCLA-523. Southwest Museum Area 2, Site D. Coll. 1962 by R. J. Fitzwater.

UCLA-524. Tule Springs $>31,000$

Snail shells from erosion remnant from caliche cap in upper part of "green pond" unit. Coll. 1962 by R. E. Taylor, M. Levine and C. V. Haynes. Comment (C.V.H.) : the "green pond" unit is clearly older than $40,000 \mathrm{yr}$ and UCLA-501 may be in error. Two independent measurements were run in the laboratory with excellent agreement, so it appears that the spring may have been active again $26,000 \mathrm{yr}$ ago or the sample itself may be a mixture of younger material with the older.

\section{Tule Springs series, lacustrine phase}

Overlying the "green pond" unit is a tan alluvium and a gray lacustrine mudstone with strong calichification. Neither unit contained evidence of human occupation and only the lacustrine unit contained suitable $\mathrm{C}^{\mathbf{1 4}}$ samples.

UCLA-513. Tule Springs

Charcoal in contact zone at base of upper gray-white snail-bearing lacus- 
trine mudstone associated with bone fragments (some mammoth) and two mammoth teeth, ca. $1000 \mathrm{ft} \mathrm{W}$ of UCLA-501. Coll. 1962 by C. V. Haynes and R. E. Taylor.

UCLA-520. Tule Springs

Fine grained carbon from dark gray zone in block of caliche cap associated with burned wrist bones of camel. Should provide a minimum age on lower part of lacustrine unit. Upper part has been eroded at this locality. Approx. $800 \mathrm{ft}$ W of UCLA-501. Coll. 1962 by C. V. Haynes.

\section{UCLA-536. Tule Springs}

$22,600 \pm 550$

20,650 в.с.

Snail shells from erosion remnant in lacustrine unit overlying "green pond" sediments. Coll. 1963 by C. V. Haynes.

Comments (C.V.H.) : UCLA-513 may be redeposited from the "green pond" unit and hence too old. UCLA-520 and 536 indicate that the maximum level of the ancient lake is contemporary with the last major North American continental glaciation (late Wisconsin).

\section{Tule Springs series, early post-playa phase}

The lacustrine phase, represented by the playa unit, was followed by an alluvial phase occupying stream channels cut into earlier units and containing a vertebrate fauna and widely dispersed artifacts indicating man's presence. Ancient carbonate-depositing springs are associated with the channel and obviously supplied water to the stream.

\section{UCLA-503. Tule Springs}

$13,400 \pm 1000$

Tufa from possible outcrop of spring in "green pond" sediments. The uncorrected carbonate date is 15,920 \pm 220 . Coll. 1962 by C. V. Haynes.

\section{UCLA-507. Tule Springs}

$12,270 \pm 200$

10,320 в.с.

Charcoal from channel fill, "350 ft W Cut," associated with flakes and camel, horse, and mammoth bones. $50 \mathrm{ft} \mathrm{N}$ of UCLA-505. Coll. 1962 by W. Stein.

\section{UCLA-637. Tule Springs}

$11,900 \pm 250$ 9950 в.с.

Charcoal from upper portion of a channel fill, " $350 \mathrm{ft} W$ Cut," composed of dark gray clayey sand and fine caliche gravel. $60 \mathrm{ft}$ NW of UCLA-636. Coll. 1962 by W. Stein.

\section{UCLA-509. Tule Springs}

$$
\begin{aligned}
& 12,450 \pm 230 \\
& 10,500 \text { в.C. }
\end{aligned}
$$

Charcoal, McCown camel site, from dark gray silt in broken and rolled caliche, associated with stone awl. McCown camel site is $1.5 \mathrm{mi} \mathrm{W}$ of " $350 \mathrm{ft}$ W Cut." Coll. 1962 by R. J. Fitzwater.

\section{UCLA-514. Tule Springs}

$12,300 \pm 350$

10,350 в.c.

Charcoal lumps, McCown camel site, in rolled caliche gravel in channel fill, associated with small bone tool and camel bone. $2 \mathrm{ft} \mathrm{E}$ and $1 \mathrm{in}$. higher than UCLA-509. Date should agree with UCLA-509. Coll. 1962 by M. Levine. 


\section{UCLA-512. Tule Springs}

Charcoal, Fenly Hunter Cut, mixed with gray silty clay on caliche gravel lens within ancient channel fill, $12 \mathrm{ft}$ below surface, associated with small bone tool and fragments of camel bone. Coll. 1962 by B. Twitchel, K. Dove, B. Orlins and C. V. Haynes.

\section{UCLA-604. Tule Springs}

$$
12,400 \pm 200
$$

Charcoal, Fenly Hunter Cut, in gray-brown silt lens in rolled caliche, associated with bone tool and teeth of horse, mammoth, and camel. Coll. 1963 by J. E. Mawby.

\section{UCLA-518. Tule Springs}

$$
\begin{aligned}
& 12,650 \pm 200 \\
& 10,700 \text { в.C. }
\end{aligned}
$$

Plant remains, Site 6, in lower fill of channel which was cut after formation of caliche cap. Associated with camel bones. Coll. 1962 by R. E. Taylor and N. Noble.

\section{UCLA-521. Tule Springs}

$$
12,920 \pm 220
$$$$
10,970 \text { в.c. }
$$

Charcoal lumps from Trench 9, Site 5, 13 in. below surface, in upper portion of channel fill in gray silty sand resting on caliche gravel. Associated with mammoth, antelope, and camel. Site 5 is $1 \mathrm{mi} \mathrm{E}$ of " $350 \mathrm{ft} \mathrm{W}$ Cut." Coll. 1962 by D. Tuohy and crew.

\section{UCLA-522. Tule Springs}

$13,100 \pm 200$ 11,150 в.C.

Charcoal lumps from Trench 9, Site 5, 21 in. below surface, in lower portion of channel fill in gray silty sand resting on caliche gravel. Associated with mammoth, antelope, and camel. Possible associations with burned digging stick. Coll. 1962 by D. Tuohy.

\section{UCLA-543. Tule Springs}

$$
\begin{aligned}
& 13,900 \pm 300 \\
& 11,950 \text { в.с. }
\end{aligned}
$$

Snail shells, Site 5, in channel fill, 26 to 30 in. below surface. Associated with fauna of large vertebrates. Coll. 1963 by D. Tuohy, B. Twitchel and P. Brozanovich. Comment: age computed on basis of 0.95 NBS oxalic acid, and therefore probably too great.

\section{UCLA-546. Tule Springs}

$14,400 \pm 1000$

$$
12,450 \text { в.c. }
$$

Tufa in caliche gravel of channel fill, Site 5, 39 in. below surface. The uncorrected carbonate date is $16,900 \pm 300$. Same general area as UCLA521, 522 and 543. Coll. 1963 by D. Tuohy, B. Twitchel and P. Brozanovich.

\section{UCLA-552. Tule Springs}

$$
13,000 \pm 200
$$

line in spring-laid sand, $W$ side of Las Vegas wash, $400 \mathrm{ft} \mathrm{NW}$ of grid area. Coll. 1963 by C. V. Haynes.

Comment (C.V.H.) : dates indicate rather brief period for deposition of the early post-playa unit between 13,500 and 12,000 yr ago. Man first appeared on the scene during this period. The tufa dates (UCLA-503 and 546) confirm the 
association of springs with the channel sediments and UCLA-503 clearly indicates that some springs active more than $40,000 \mathrm{yr}$ ago were again active 13,000 to $14,000 \mathrm{yr}$ ago.

\section{Tule Springs series, middle post-playa phase}

The early post-playa sediments are overlain by buff-colored silts representing the middle post-play alluvial phase, during which time large quantities of floodplain alluvium covered the area.

\section{UCLA-505. Tule Springs \\ $10,000 \pm 200$ 8050 в.C.}

Charcoal and dark-colored plant remains in a channel fill, "350 ft W Cut." Directly associated with flakes and bone. Coll. 1962 by W. Stein.

\section{$\begin{array}{ll}\text { UCLA-508. Tule Springs } & 11,200 \pm 300\end{array}$}

$\mathrm{ft}$ W Cut $" 7.6 \mathrm{ft}$ below surface, 20 and C. V. Haynes.

\section{UCLA-636. Tule Springs}

$11,500 \pm 500$ 9550 в.с.

Charcoal from lower portion of a channel fill, "350 ft W Cut," 18 in. below surface, $30 \mathrm{ft}$ W of UCLA-507. Associated with camel bones. Coll. 1962 by W. Stein.

\section{UCLA-519. Tule Springs}

$7480 \pm 120$

5530 в.C.

Plant remains in late alluvium, Fenly Hunter Cut $(1100 \mathrm{ft}$ E of " $350 \mathrm{ft}$ W Cut"), representing final stages of stream aggradation, $5.5 \mathrm{ft}$ below surface. Coll. 1962 by R. E. Taylor and M. Levine.

\section{UCLA-510. Tule Springs}

$9000 \pm 1000$ 7050 в.c.

Finely powdered charcoal and silt, Fenly Hunter Cut, in upper part of laminated buff silt unit, $2 \mathrm{ft}$ below surface. Apparently result of prairie fire. The large error is due to small amount of sample. Coll. 1962 by B. Twitchel, P. Brozanovich, C. V. Haynes.

Comment (C.V.H.) : these dates are internally consistent and support the geological estimate of their age.

\section{Tule Springs series, protohistoric alluvial phase}

The middle post-playa phase was followed by extensive erosion and channeling for which there are no $\mathrm{C}^{14}$ dates. The last period of alluviation in the area is represented by the protohistoric alluvium which contains numerous hearths and charcoal lenses and is now heing eroded.

\section{UCLA-515. Tule Springs}

$360 \div 120$

\section{A.v. 1590}

Charcoal lumps in and around burned lens in late alluvial silt and sand filling of arroyo $\left(36^{\circ} 17^{\prime} 15^{\prime \prime} \mathrm{N}\right.$ Lat, $115^{\circ} 9^{\prime} 55^{\prime \prime} \mathrm{W}$ Long). Coll. 1962 by $\mathrm{C}$. V. Haynes. 


\section{UCLA-516. Tule Springs}

Charcoal lumps in burned lens in late alluvial silt, sand and gravel filling of arroyo $\left(36^{\circ} 17^{\prime} 18^{\prime \prime} \mathrm{N}\right.$ Lat, $115^{\circ} 10^{\prime} \mathrm{W}$ Long). Coll. 1962 by C. V. Haynes.

\section{UCLA-635. Tule Springs}

$\mathbf{5 7 0} \pm \mathbf{8 0}$

Charcoal from base of late prehistoric alluvial fill with tree stump on top $\left(36^{\circ} 16^{\prime} 20^{\prime \prime} \mathrm{N} \mathrm{Lat}, 115^{\circ} 10^{\prime} 47^{\prime \prime} \mathrm{W}\right.$ Long). Should date beginning of last phase of alluviation in arroyos near site. Coll. 1963 by C. V. Haynes and P. Mehringer.

\section{UCLA-639. Tule Springs}

$$
\mathbf{3 3 0} \pm \mathbf{8 0}
$$

Partially burned wood from upper $6 \mathrm{in}$. of alluvium fill in arroyo $\left(36^{\circ}\right.$ $16^{\prime} 28^{\prime \prime} \mathrm{N}$ Lat, $115^{\circ} 10^{\prime} 48^{\prime \prime} \mathrm{W}$ Long). Same arroyo as UCLA-635, so should date end of last phase of alluviation in arroyos near site. Coll. 1963 by C. V. Haynes and P. Mehringer.

\section{UCLA-640. Tule Springs}

$$
\mathbf{2 0 0} \pm \mathbf{8 0}
$$

Mesquite wood from stump on late prehistoric alluvial fill (see UCLA635) $\left(36^{\circ} 16^{\prime} 28^{\prime \prime} \mathrm{N}\right.$ Lat, $115^{\circ} 10^{\prime} 48^{\prime \prime} \mathrm{W}$ Long). Mesquite is growing near the site today. Coll. 1963 by C. V. Haynes and P. Mehringer.

Comment (C.V.H.) : the dates confirm geological and archaeological estimates and complete the young end of the sedimentary record.

\section{Corn Creek Site}

About $15 \mathrm{mi} \mathrm{NW}$ of Tule Springs lithic artifacts were found in ancient sand dunes at Corn Creek ( $36^{\circ} 27^{\prime} \mathrm{N}$ Lat, $115^{\circ} 23^{\prime} \mathrm{W}$ Long) and further investigation disclosed numerous hearths. Charcoal from seven hearths was collected to establish the time period of occupation of this site. Coll. Jan .1963 by C. V. Haynes and B. Orlins.

\section{Corn Creek series, hearths}

\section{UCLA-525. Corn Creek, Hearth 3 \\ $4440 \pm 100$}

2490 в.C.

Charcoal from Hearth 3, 6 in. below surface, $2 \mathrm{ft}$ above caliche cap.

\section{UCLA-526. Corn Creek, Hearth 1}

$5200 \pm 100$

Charcoal from Hearth 1, 6 in. above caliche cap, $20 \mathrm{ft}$ from UCL A. 525.

UCLA-531. Corn Creek, Hearth 6

Charcoal from Hearth 6.

UCLA-532. Corn Creek, Hearth 7

Charcoal from Hearth 7.

UCLA-533. Corn Creek, Hearth 8

Charcoal from Hearth 8.
$4580 \pm 100$

2630 в.c.

$4610 \pm 100$

2660 B.c.

$4900 \pm 100$

2950 в.C. 


\section{UCLA-534. Corn Creek, Hearth 9}

Charcoal from Hearth 9.

UCLA-535. Corn Creek, Hearth 10
$4380 \pm 100$

2430 в.c.

$4030 \pm 100$ 2080 в.C.

Charcoal from Hearth 10.

Comment (C.V.H.) : a single period of intermittent occupation of about 1000 $\mathrm{yr}$ is indicated.

\section{Spring Activity Areas}

Evidence of past spring activity at the main Tule Springs site is abundant although no springs exist at present. Springs with active discharge are, however, scattered around the surrounding areas along with many mounds formed from past spring activity. Samples of occupational evidence and of organic material from springs in surrounding areas were accordingly taken to investigate times of emergence and life of various springs in the general area of Tule Springs.

Tule Springs series, active and inactive springs

\section{UCLA-540. Gilcrease, Spring 7}

$$
315 \pm 65
$$

A.D. 1635

Charcoal from hearth in alluvial silt of Spring 7, Gilcrease Ranch, $4 \mathrm{mi}$ W of Tule Springs site ( $36^{\circ} 18^{\prime} 30^{\prime \prime} \mathrm{N}$ Lat, $115^{\circ} 16^{\prime} \mathrm{W}$ Long). Pueblo and Paiute occupation on top. Coll. Jan. 23, 1963 by C. V. Haynes.

UCLA-527. Gilerease, Spring 7

$$
1450 \pm 100
$$

\section{A.D. 500}

Fine-grained organic matter and carbon in mound of spring $\left(36^{\circ} 18^{\prime} 30^{\prime \prime}\right.$ N Lat, $115^{\circ} 16^{\prime} \mathrm{W}$ Long) that went dry in 1948. Southern Paiute and possibly Pueblo occupation sites and pottery exist around spring mound. Coll. 1962 by C. V. Haynes.

\section{UCLA-537. Gilcrease, Spring 4}

$$
9920 \pm 150
$$

Black organic soil from the interior of spring mound $\left(36^{\circ} 17^{\prime} 30^{\prime \prime} \mathrm{N}\right.$ Lat, $115^{\circ} 15^{\prime} 30^{\prime \prime}$ WLong) which became inactive ca. 40 yr ago. Should date emergence of spring. Coll. 1963 by C. V. Haynes.

\section{UCLA-529. Gilcrease, Spring 4-A \\ $9200 \pm 250$}

7250 в.C.

Fine-grained organic matter in mound of ancient spring $\left(36^{\circ} 17^{\prime} 30^{\prime \prime} \mathrm{N}\right.$ Lat, $115^{\circ} 15^{\prime} 30^{\prime \prime} \mathrm{W}$ Long). Several strongly weathered artifacts were found on the surface of the mound. Coll. 1963 by C. V. Haynes.

\section{UCLA-539. Gilerease, Spring 4-A}

$$
\begin{gathered}
25,300 \pm 2500 \\
23,350 \text { в.c. }
\end{gathered}
$$

Wood fragments from lens located on contact between green clay and overlying gray clay silt below organic soil dated by UCLA-529 (9200 \pm 250$)$. Coll. 1963 by C. V. Haynes and R. E. Taylor.

\section{UCLA-530. Corn Creek}

$$
10,800 \pm 300
$$$$
8850 \text { в.c. }
$$

Fine-grained organic matter from center of mound of ancient spring, 6 
mi NW of Corn Creek game range headquarters $\left(36^{\circ} 29^{\prime} \mathrm{N}\right.$ Lat, $115^{\circ} 27^{\prime} \mathrm{W}$ Long). Weathered artifacts found on surface. Coll. 1963 by C. V. Haynes.

\section{UCLA-538. Corn Creek, Spring 4}

A.D. 1370

Black organic soil from top of mound surrounding modern spring in Corn Creek area, $13 \mathrm{mi} \mathrm{NW}$ of Tule Springs site $\left(36^{\circ} 26^{\prime} 30^{\prime \prime} \mathrm{N} \mathrm{Lat}, 115^{\circ} 21^{\prime} \mathrm{W}\right.$ Long). Coll. 1963 by C. V. Haynes.

\section{UCLA-541. Corn Creek, Spring 3}

Organic mat from under gray silt of ancient spring, Corn Creek $\left(36^{\circ} 27^{\prime}\right.$ $4^{\prime \prime} \mathrm{N}$ Lat, $115^{\circ} 21^{\prime} 8^{\prime \prime} \mathrm{W}$ Long). Should date emergence of springs in this area which was presumably related to faulting. Coll. 1963 by C. V. Haynes.

\section{UCLA-542. Corn Creek, Spring 8}

Organic mat from under gray silt of ancient spring $\left(36^{\circ} 28^{\prime} 27^{\prime \prime} \mathrm{N}\right.$ Lat, $115^{\circ} 22^{\prime} 36^{\prime \prime}$ W Long) . Coll. 1963 by C. V. Haynes.

\section{UCLA-548. Tule Springs}

$8000 \pm 400$

Burned wood from below pink-to-buff silt of ancient spring near a scarp, $3 \mathrm{mi} \mathrm{S}$ of Tule Springs $\left(36^{\circ} 16^{\prime} \mathrm{N}\right.$ Lat, $115^{\circ} 10^{\prime} \mathrm{W}$ Long). Mudstones on eroded surface of scarp associated with rodent fauna and snail shells. Coll. 1963 by C. V. Haynes and J. F. Lance.

\section{UCLA-549. Tule Springs}

$9520 \pm 300$

7570 в.c.

Organic mat below pink-to-gray silt of ancient spring associated with camel teeth and snail fauna, Location 3, 1-105 $\left(36^{\circ} 16^{\prime} 20^{\prime \prime} \mathrm{N}\right.$ Lat, $115^{\circ} 11^{\prime}$ 50" W Long). Coll. 1963 by C. V. Haynes.

\section{UCLA-550. Tule Springs}

$$
11,100 \pm 200
$$

9150 в.c.

Organic mat below pink-to-gray silt of ancient spring associated with snail fauna, Location 4-A, 1-105 (36 $16^{\prime} 18^{\prime \prime} \mathrm{N}$ Lat, $115^{\circ} 11^{\prime} 50^{\prime \prime} \mathrm{W}$ Long). Coll. 1963 by C. V. Haynes.

\section{UCLA-551. Tule Springs}

$9350 \pm 200$

7400 в.c.

Organic mat below pink-to-gray silt of ancient spring. Associated with snail fauna. Location 7, 1-105 (36 $16^{\prime} 15^{\prime \prime} \mathrm{N}$ Lat, $115^{\circ} 11^{\prime} 45^{\prime \prime} \mathrm{W}$ Long). Coll. 1963 by C. V. Haynes.

\section{UCLA-638. Tule Springs}

Charcoal from mound of now-inactive spring near base of scarp $3.8 \mathrm{mi}$ $\mathrm{SW}$ of Tule Springs site $\left(36^{\circ} 15^{\prime} 49^{\prime \prime} \mathrm{N}\right.$ Lat, $115^{\circ} 12^{\prime} 14^{\prime \prime} \mathrm{W}$ Long). Mound covered with a deposit, up to $2 \mathrm{ft}$ thick, consisting of charcoal, silt, burnt caliche fragments, pottery and flint. Date should indicate time of occupation when spring was presumably flowing. Coll. 1963 by C. V. Haynes and R. Shutler, Jr. 


\section{UCLA-641. Tule Springs}

Tufa outcrop near scarp, $3.4 \mathrm{mi}$ SE of Tule Springs site $\left(36^{\circ} 16^{\prime} 42^{\prime \prime} \mathrm{N}\right.$ Lat, $115^{\circ} 9^{\prime} 14^{\prime \prime} \mathrm{W}$ Long). The uncorrected carbonate date is $15,000 \pm 300$. Coll. 1963 by C. V. Haynes and R. Shutler, Jr.

\section{UCLA-642. Tule Springs}

Tufa outcrop near scarp, $3.5 \mathrm{mi}$ SE of Tule Springs site $\left(36^{\circ} 17^{\prime} 22^{\prime \prime} \mathrm{N}\right.$ Lat, $115^{\circ} 8^{\prime} 16^{\prime \prime} \mathrm{W}$ Long). Tufa believed deposited by springs and should provide minimum date on fauliing in area. The uncorrected carbonate date is 11,800 \pm 250 . Coll. 1963 by C. V. Haynes and R. Shutler, Jr.

Comment (C.V.H.) : the dates clearly indicate that some of the springs have been active at various times in the past. In the final geological analysis it is expected that these dates will permit the understanding of a time-space sequence of faulting in the area. They will also help demonstrate the movement of prehistoric man in response to the appearance or disappearance of springs.

\section{B. Western United States}

\section{Yosemite series, California}

Burned wood from site Mrp-105, alt $6000 \mathrm{ft}, 1.2 \mathrm{mi}$ SE Crane Flat Ranger Station, Yosemite National Park, California $\left(37^{\circ} 46^{\prime} \mathrm{N}\right.$ Lat, $119^{\circ} 46^{\prime} \mathrm{W}$ Long). The region in which this site is located has been an area of cultural contact between the people inhabiting the Central Valley of California and the Great Basin to the East. These samples should thus provide absolute dates for the Sierran archaeological sequence and also an indication of time required for transmission of cultural traits over a given distance and hence on the migrations of aboriginal peoples. Coll. by R. J. Fitzwater; subm. by C. W. Meighan, Anthropol. Dept., Univ. of California, Los Angeles.

\section{UCLA-276. Yosemite Park}

$$
950 \pm 70
$$

\section{A.D. 1000}

Charcoal from Pit 22C, 18 to 24 in. depth. Associated with an artifact assemblage containing Desert Side-notched projectile points believed to have their origin in the Southwest about A.D. 900.

\section{UCLA-277. Yosemite Park}

$$
1580 \pm 80
$$

A.D. 370

Charcoal from Pit 22C, 36 to 42 in. depth. Should date transition period which contains Elko Eared, Elko Contracting Stem and Elko Corner-notched projectile points which have been dated at a site in the Great Basin at 2950 $\pm 200 \mathrm{yr}$ (LJ-203, La Jolla II).

\section{UCLA-278. Yosemite Park}

$$
\begin{gathered}
2040 \pm 100 \\
90 \text { B.c. }
\end{gathered}
$$

Charcoal from Pit 22C, 48 to 54 in. depth, deepest portion of site. Contains Pinto projectile points identical to those from Danger Cave dated as $8960 \pm 340$ (C-640, Chicago III). 
Comment (C.W.M.) : UCLA-276 is in good agreement with the archaeological evidence from other sites. UCLA-277 and 278 appear too young-either the artifacts in association persisted over a very long time span, or there is a contamination or stratigraphic problem yielding erroneous dates, or the dating evidence from other sites is in error.

\section{Southfork Shelter series, Nevada}

Southfork Shelter is a refuse-filled rockshelter near mouth of South Fork of Humboldt River, Elko County, Nevada $\left(40^{\circ} 44^{\prime} 8^{\prime \prime} \mathrm{N}\right.$ Lat, $115^{\circ} 51^{\prime} 40^{\prime \prime} \mathrm{W}$ Long). In the excavations, a sequence of projectile point types was recovered, the upper part of the series cverlapping with that from Wagon Jack Shelter, Churchill County, Nevada (Heizer and Bennyhoff, 1961). Samples selected to date earliest occupation of site. Subm. by R. F. Heizer, Univ. of California, Berkeley.

\section{UCLA-295. Southfork Shelter, Nevada}

$4360 \pm 300$

2410 B.C.

Charcoal, probably sagebrush, 120 in. below surface, from refuse midden in Pit 1.

\section{UCLA-296. Southfork Shelter, Nevada}

$4310 \pm 400$

2360 B.C.

Charcoal from depth of 94 to 100 in. in Pit 2 in midden deposit. Comment: date is consistent with that of LJ-203 (3320 \pm 100, LJ II) from depth of 72 in. in Pit 2.

\section{UCLA-298. Leonard Rockshelter, Nevada \\ $13,000 \pm 1000$ \\ 11,050 в.c.}

Shells of small gastropods (Amnicola sp.) in sandy beach deposit forming base of the post-lacustrine deposits of Leonard Rockshelter, Nevada $\left(40^{\circ} 2^{\prime} 5^{\prime \prime}\right.$ $\mathrm{N}$ Lat, $118^{\circ} 29^{\prime} \mathrm{W}$ Long). A number of $\mathrm{C}^{14}$ dates from the site have been secured (see Heizer, 1951 for list), the oldest of which (C-599, 11,199 \pm 570 , Chicago II) is for bat guano lying directly on the sand and gravel beach deposit formed by the stand of Lake Lahontan just before its final lowering. Alt of top of this "beach" is $4175 \mathrm{ft}$. Comment (R.F.H.) : age of UCLA-298 is consistent with other evidence of the final high stand of Lake Lahontan. Subm. by R. F. Heizer.

\section{UCLA-297. Fernandez Site, California}

Charcoal from depth of 76 in. in Pit A9 in shellmound $\left(38^{\circ} 0^{\prime} 2^{\prime \prime} \mathrm{N} \mathrm{Lat}\right.$, $122^{\circ} 12^{\prime} 31^{\prime \prime} \mathrm{W}$ Long), $4.5 \mathrm{mi}$ from the shore of San Francisco Bay. Comment (R.F.H.) : age of sample is consistent with cultural evidence (Davis, 1960) and other $\mathrm{C}^{14}$ dates for the San Francisco Bay region (Heizer, 1958). Subm. by R. F. Heizer.

\section{Goleta Valley series, California}

Shell samples from an early "milling stone" camp site, 4SBa 142, Glen Annie Canyon, Goleta Valley, California (34 $25^{\prime} 40^{\prime \prime} \mathrm{N}$ Lat, $119^{\circ} 52^{\prime} 40^{\prime \prime} \mathrm{W}$ Long). Dating of this site should establish the age of the Oak Grove horizon which occurs throughout the Santa Barbara coastal area. All ages have been 
expressed with respect to shells collected in 1880 on California coast. Coll. and subm. by R. C. Owen, Anthropol. Dept., Univ. of California, Santa Barbara.

\section{UCLA-605. Goleta Valley}

$6880 \pm 120$

4930 в.C.

Shells (Saxidomus nuttallii), Pit 3, 12 to 18 in. depth, from matrix of a burial typical of this site.

\section{UCLA-606. Goleta Valley}

$$
\begin{aligned}
& 6980 \pm 120 \\
& 5030 \text { в.c. }
\end{aligned}
$$

Shells, various species, Pit 4, 12 to 18 in. depth. Associated with a burial not typical of other burials on this site.

\section{UCLA-607. Goleta Valley}

$$
7270 \pm 120
$$$$
5320 \text { в.c. }
$$

Shells (Saxidomus nuttallii), Pit 4, 12 to 18 in. depth. Heaped over a burial complex.

\section{UCLA-608. Goleta Valley}

$$
\begin{aligned}
& 6380 \pm 120 \\
& 4430 \text { в.C. }
\end{aligned}
$$

Shells, various species, Pit 18, 24, to 30 in. depth. From section of site in which burials did not occur.

Comment (R.C.O.) : these dates support the contention, developed in the site report (UCLA Archaeological Survey Annual Report, in preparation) that $4 \mathrm{SBa} 142$ was a temporary camp site utilized for at least $1000 \mathrm{yr}$. The burials were placed on the soil surface when the midden was in the early stages of being formed. A terminal date for habitation of the site has not been established.

\section{UCLA-647. Bodega Bay, California}

Wood from test boring at Bodega Bay, California $\left(38^{\circ} 17^{\prime} \mathrm{N}\right.$ Lat, $122^{\circ}$ $58^{\prime}$ W Long), proposed test site of atomic power station, $77 \mathrm{ft}$ below surface and $18 \mathrm{ft}$ above mean sealevel. Approx. $125 \mathrm{ft}$ of alluvial soils overlay the granite diorite bedrock. Occasional shear zones are present in the granite, but no indication of displacement in overlying material has been found. Date should thus give a minimum period of time since last displacement of the granite. Coll. and subm. by F. F. Mautz, Pacific Gas and Electric Co., San Francisco.

\section{UCLA-259. San Ramon, California}

Charcoal from soil matrix of burial, Site CCO-308, San Ramon Valley. Alamo, California $\left(37^{\circ} 45^{\prime} \mathrm{N}\right.$ Lat, $122^{\circ} 11^{\prime} \mathrm{W}$ Long). Site has three clear occupational levels. Sample from base of lowest level at depth of $16.5 \mathrm{ft}$ below surface. Coll. 1962 by Dave Frederickson; subm. by G. C. Kennedy, Inst. of Geophysics, Univ. of California, Los Angeles.

\section{UCLA-271. Salisbury Canyon, California}

$120 \pm 80$

Fragments of large storage basket from dry cave in Salisbury Canyon $\left(119^{\circ} 40^{\prime} \mathrm{N}\right.$ Lat, $34^{\circ} 5^{\prime} \mathrm{W}$ Long) ca. $6 \mathrm{mi} \mathrm{N}$ of New Cuyama. Part of large collection of perishable Canalino-type materials recovered in the late 1920's from three dry caves. In addition, there were artifacts of wood, shell, bone, tule 
and feathers; nearby caves were decorated with pictographs. Some of the material was Spanish contact. Coll. and subm. by Campbell Grant, Santa Barbara Mus. of Nat. History, Santa Barbara, California.

\section{UCLA-289. Descanso, California}

$200 \pm 65$

Wood from burl root crown of living Red Shank (Adenostoma sparsifolium ), $10 \mathrm{mi} \mathrm{SE}$ of Descanso, California $\left(32^{\circ} 10^{\prime} 00^{\prime \prime} \mathrm{N} \mathrm{Lat,} 116^{\circ} 5^{\prime} 10^{\prime \prime}\right.$ W Long). This chaparral shrub is considered a relic species, being restricted to four regions in Southern California. Burls are suspected of living for considerable periods as they are not destroyed by brush fires. Sample therefore taken from center of one of largest burls. Coll. by T. L. Hanes; subm. by Harold Mooney, Dept. of Botany, Univ. of California, Los Angeles.

\section{Carpinteria series, California}

Large trunks of trees and small limbs exposed in the Carpinteria formation by a bulldozed roadway E of the town of Carpinteria $\left(34^{\circ} 23^{\prime} 30^{\prime \prime} \mathrm{N}\right.$ Lat, $119^{\circ} 3 \mathrm{l}^{\prime} 00^{\prime \prime} \mathrm{W}$ Long). As the wood was impregnated with tar, center portions of samples were shredded and washed with benzene. Coll. Feb. 1962 by G. J. Fergusson and P. C. Orr; subm. by P. C. Orr, Santa Barbara Mus. Nat. History, California.

UCLA-180. Carpinteria formation luvium.

Wood from depth of $7 \mathrm{ft}$ in formation which is overlaid by $3 \mathrm{ft}$ of al-

UCLA-181. Carpinteria formation

$>38,000$

Wood from depth of $4 \mathrm{ft}$ in formation.

Comment (P.C.O.) : Cheney and Mason (1934) recognized a difference in the floras of the Carpinteria and Santa Cruz Formations, but were unable to determine whether this was due to time or geographic differences. $\mathrm{C}^{14}$ dates for the Santa Cruz Formation on Santa Cruz Island, UCLA-144, 14,200 \pm 250 (UCLA II) and Santa Rosa Island, L-244, 15,820 \pm 280 (Lamont IV), show that the two Formations are of different age.

\section{UCLA-275. Topanga Canyon, California \\ $3000 \pm 100$ \\ 1050 в.C.}

Shell (Mytilus californianus) from midden at Parker Mesa (LAn-215) Topanga Canyon, Los Angeles County, California $\left(34^{\circ} 2^{\prime} \mathrm{N}\right.$ Lat, $118^{\circ} 35^{\prime} \mathrm{W}$ Long). Site (King, 1962) is on a sea terrace and sample was collected from bottom level, 18 to 24 in. of a midden-analysis pit. Associated with numerous artifacts. Should date the beginning of occupation of the site. Comment (C.W.M.) : the artifact assemblage and terrace location of the site show this site to be a part of the Early Milling Stone Horizon of Southern California, which has yielded numerous $\mathrm{C}^{14}$ dates in the 5000 to $7000 \mathrm{yr}$ range from Santa Barbara $\mathrm{S}$ to San Diego. The date given is possible but appears too young for the cultural context. Coll. by C. D. King; subm. by C. W. Meighan.

\section{Frenchman Flat series, Nevada}

Plant remains from abandoned middens of packrat in shallow caves in 
limestone in the creosote-bush and Coleogyre zones surrounding Frenchman Flat, Nevada. Deposits vary in thickness up to maximum of $2 \mathrm{ft}$ and contain juniper (Juniperus osteosperma) twigs and seeds throughout. Organic residue after $\mathrm{HCl}$ treatment was used for dating. The past occurrence of juniper in this area implies a rainfall of 10 to 15 in. per yr, compared to less than 5 in. at present. Other samples beloning to this series are UCLA-107, UCLA-I; and UCLA-150 and 151, UCLA II. For a more detailed report on implications of this series, see Wells and Jorgensen (1964). Coll. and subm. by P. V. Wells, Univ. of Kansas, Lawrence, Kansas.

\section{UCLA-555. Ranger Mountains}

$17,450 \pm 300$ 15,500 в.с.

Site 1 , alt $3600 \mathrm{ft}\left(36^{\circ} 47^{\prime} \mathrm{N}\right.$ Lat, $115^{\circ} 53^{\prime} \mathrm{W}$ Long $)$. Lower part of deposit.

\section{UCLA-556. Ranger Mountains}

$16,800 \pm 300$

Site 2, alt $3700 \mathrm{ft}$. Lower part of deposit.

UCLA-557. Mercury Ridge

14,850 в.c.

, E Long). Upper part of deposit which was ca. $2 \mathrm{ft}$ thick.

UCLA-558. Mercury Ridge

Same cave as UCLA-557. Lower part of deposit.

\section{UCLA-559. Mercury Ridge}

Site 2, E end of Mercury Ridge, alt $4600 \mathrm{ft}$. Lower part of deposit which was ca. $1 \mathrm{ft}$ thick.

\section{UCLA-560. Narrow Canyon}

$7800 \pm 150$

5850 в.c.

Site 1 , alt $4200 \mathrm{ft}\left(36^{\circ} 42^{\prime} \mathrm{N}\right.$ Lat, $115^{\circ} 53^{\prime} \mathrm{W}$ Long $)$. Lower part of deposit which was ca. $1 \mathrm{ft}$ thick.

\section{UCLA-561. Narrow Canyon}

$12,700 \pm 200$

Site 2, alt $4100 \mathrm{ft}$. Lower part of deposit.

UCLA-644. Aysees Peak Long).

Deposit with abundant twigs, Aysees Peak ( $36^{\circ} 53^{\prime} \mathrm{N}$ Lat, $115^{\circ} 49^{\prime} \mathrm{W}$

\section{Birch Creek Valley series, Idaho}

Charcoal from two rockshelters, 10-CL-100 and Jackknife Cave, situated well above the flood plain of Birch Creek Valley of eastern Idaho $\left(44^{\circ} 05^{\prime} \mathrm{N}\right.$ Lat, $112^{\circ} 55^{\prime} \mathrm{W}$ Long). Site 10-CL-100 is filled with fan deposits, sloping out of the Beaverhead Mountains and past the front of the shelter. Jackknife Cave is a very dry shelter across the valley from 10-CL-100. Perishable material such as matting and basketry has thus been preserved along with many large side-notched points. Coll. 1962 and subm. by E. H. Swanson, Jr., Idaho State Univ. Mus., Pocatello. 
UCLA-253. Rockshelter, 10-CL-100

Test Pit 1, Level 3, Hearth II.

UCLA-252. Rockshelter, 10-CL-100

Test Pit 1, Level 3, Hearth I.

UCLA-254. Rockshelter, 10-CL-100
$365 \pm 80$

A.D. 1585

$1420 \pm 80$

A.D. 530

$1820 \pm 80$

Test Pit 2, Level 4. Associated with corner-notched and corner-removed projectile points.

UCLA-255. Rockshelter, 10-CL-100

$4500 \pm 100$

Test Pit 2, Level 8.

UCLA-256. Rockshelter, 10-CL-100

$3170 \pm 80$

1220 в.c.

Test Pit 2, Level 8. Associated with side-notched projectile points.

UCLA-257. Jackknife Cave

Test Pit 1, Level 3.

UCLA-258. Jackknife Cave

Test Pit 1, Level 6.
$385+65$

A.D. 1565

$1700 \pm 75$

A.D. 250

\section{Mexico}

\section{Cuicuilco Quarry series, Mexico City, Mexico}

Charcoal samples from the sub-Pedregal mound area (Cuicuilco-B) in Peña Pobre Quarry $0.3 \mathrm{mi} \mathrm{W}$ of the pyramid at Cuicuilco just $\mathrm{S}$ of Mexico City $\left(19^{\circ} 18^{\prime} \mathrm{N}\right.$ Lat, $99^{\circ} 11^{\prime} \mathrm{W}$ Long). A summary of the 1957 excavations at Cuicuilco-B directed by R. F. Heizer with pertinent bibliography appears in Heizer and Bennyhoff (1958). Additional dates appear in Yale IV (Y-437) and UCLA-II (UCLA-205-212, 228). Of the dates reported here, UCLA-602, 603 were coll. by R. F. Heizer, R. F. Millon and R. J. Squier in 1957, UCLA597 was coll. by J. A. Bennyhoff in 1961, and the remainder were coll. by P. and R. Krotser in 1962. Subm. by R. F. Heizer, Univ. of California, Berkeley and J. A. Bennyhoff, Univ. of Rochester, New York.

UCLA-594. Cuicuilco B-9

Charcoal from Mound 1, Trench 10, Pit 1, depth 4.36 to $4.51 \mathrm{~m}$ below Datum Al. Scattered through Middle Zacatenco midden used as fill for Ticoman I structure. Date satisfactory for Middle Zacatenco phase.

\section{UCLA-595. Cuicuileo B-10}

$$
2490 \pm 100
$$

540 в.C.

Charcoal from Mound 1, Trench 10, Pit 2, depth 4.51 to $4.66 \mathrm{~m}$ below Datum Al. Scattered through Middle Zacatenco midden used as fill for Ticoman I structure. Date satisfactory for Middle Zacatenco phase. 
UCLA-596. Cuicuilco B-11

$$
2560 \pm 100
$$

610 в.с.

Charcoal from Mound 1, Trench 10, Pit 1, depth 4.66 to $4.81 \mathrm{~m}$ below Datum Al. Scattered through Middle Zacatenco midden used as fill for Ticoman I structure. Date satisfactory for Middle Zacatenco phase.

\section{UCLA-597. Cuicuilco B-12}

$3320 \pm 100$

1370 в.с.

Charcoal in combined sample from Mound 1, Trench 9, Pit 2, depth 5.06 to $5.24 \mathrm{~m}$ and Test Pit 2, depth 4.36 to $5.01 \mathrm{~m}$ below Datum Al. Scattered through same layer of Middle Zacatenco midden used as fill for Ticoman I structure. Date too old for Middle Zacatenco phase, and sample probably contained some charcoal of the Early Preclassic Tlalpan phase, occasional sherds of which did occur in the Middle Zacatenco midden.

\section{UCLA-598. Cuicuilco B-13}

$3820 \pm 100$

1870 в.c.

Charcoal from Mound 1, Trench 10, Pit 1, depth 5.11 to $6.16 \mathrm{~m}$ below Datum 1. Scattered through mixture of earth and Tlalpan phase midden used as fill for Middle Zacatenco structure. Date satisfactory for Tlalpan phase.

\section{UCLA-599. Cuicuilco B-14}

Charcoal from Mound 1, Test Pit 8, depth 6.5 to $6.7 \mathrm{~m}$ below Datum Al. Scattered through fill of gravepit through basal layer into subsoil. No sherds associated, but layer elsewhere yielded remains of Tlalpan phase. Date satisfactory for Tlalpan phase.

\section{UCLA-600. Cuicuilco B-15}

$3930 \pm 100$

Charcoal from Mound 1 , Test Pit 6, d A1. Chater ple through basal layer which elsewhere yielded remains of Tlalapan phase. Date satisfactory for Tlalpan phase.

\section{UCLA-601. Cuicuilco B-16}

$$
\begin{aligned}
& 4110 \pm 120 \\
& 2160 \text { в.c. }
\end{aligned}
$$

Charcoal in combined sample from Mound 1, Trench 10, Pit 1, depth 6.31 to $6.46 \mathrm{~m}$ and Test Pit $8 \mathrm{~W}$, depth 6.5 to $6.7 \mathrm{~m}$ below Datum A1. Scattered through basal layer which elsewhere yielded remains of Tlalpan phase. Date satisfactory for Tlalpan phase.

\section{UCLA-602. Cuicuilco B-17}

$$
2190 \pm 80
$$$$
240 \text { B.c. }
$$

Charcoal from Mound 2, Trench 5, depth 2.41 m below Datum A2 between floors 3 and 4 of Structure I. Same sample as UCLA-208 $(2100 \pm 75$, UCLA II). The average date of 195 в.c. would fall at the beginning of the Cuicuilco/Tezoyuca phases (see comment below).

\section{UCLA-603. Cuicuileo B-18}

$$
\begin{gathered}
2230 \pm 80 \\
280 \text { B.C. }
\end{gathered}
$$

Charcoal from Mound 2, Trench 5, depth $2.68 \mathrm{~m}$ below Datum A2 between floors 2 and 3 of Structure I. Re-run of same sample as UCLA-209 $(2300 \pm 70$, UCLA II $)$. The average date of 315 B.c. would fall in the Ticoman II phase (see comment below). 
General Comment (R.F.H. and J.A.B.) : UCLA-594 to 596 provide consistent dates for the Middle Zacatenco occupation at Cuicuilco. This occupation appears to be very late Middle Preclassic so a terminal date for the Middle Preclassic period of 500 B.C., (rather than 400 B.C. as suggested in UCLA II) would be supported by these new dates. Also in agreement is the Middle Zacatenco date of $2450 \pm 250$ (M-662, Michigan III) and the Tlatilco date of 2525 (M-660, Michigan III). Such a dating would provide more time for the seven Late Preclassic phases now recognized, and the following $\mathrm{C}^{14}$-based chronology can be suggested: Ticoman I, 500 to 400 в.c.; Ticoman II, 400 to 300 B.c.; Ticoman III, 300 to 200 B.c.; Cuicuilco/Tezoyuca (H4 figurine horizon), 200 to 100 B.c.; Chimalhuacan, 100 B.C. to A.D. 1; Tzacualli, A.D. 1 to 100 .

UCLA-598 to 601 provide consistent dates for the Tlalpan phase of the Early Preclassic period. The Tlalpan phase is a new ceramic complex typologically older than Early El Arbolillo. Since the latter is often dated as beginning around 1500 to 1700 B.C., an extension of the "Beginning" of the known Early Preclassic period in the Valley of Mexico back to 2000 B.c. would not be unreasonable. UCLA-210 (3980 \pm 60, UCLA II) and UCLA-212 (4050 \pm 75 , UCLA II) also fall within the range of 1870 to 2160 B.C. It should be emphasized that, of these six samples, only UCLA-598 was associated directly with Tlalpan sherds and that all six samples (including those of the basal layer) probably represent sterile-earth-and-midden-fill deposits laid down in Middle Zacatenco times. It is therefore possible that the great age of the Tlalpan phase dates is due to some mixture with preceramic charcoal, such as represented by UCLA-211 (6715 \pm 90, UCLA II). However, if such had occurred, a greater range of variation in the six dates would be expected.

UCLA-602, 603 (as well as UCLA-206, 208, 209 of UCLA II) were submitted to date the successive floors of Structure I in Mound 2. The fill of this structure was composed of Middle Zacatenco midden and various factors suggested construction during the Ticoman I phase. However, the dates obtained imply rebuliding over an extended time period. The two repeated runs (UCLA602, 208 and UCLA-603, 209) are in excellent agreement so the discrepancy does not appear to be due to the sampling.

\section{Melchor Ocampo series, Mexico}

Charcoal from extensive area of house-refuse mounds $\mathrm{N}$ of Melchor Ocampo, Michoacan, Mexico ( $17^{\circ} 57^{\prime} \mathrm{N}$ Lat, $102^{\circ} 12^{\prime} \mathrm{W}$ Long). Associated pottery suggests that site occupation period is late Postclassic (ca. A.D. 1200 to 1520). Coll. by S. Long; subm. by H. B. Nicholson, Anthropol. Dept., Univ. of California, Los Angeles.

UCLA-269. Melchor Ocampo

Charcoal from Mound A, Pit 1, 120 to $140 \mathrm{~cm}$ depth.

UCLA-270. Melchor Ocampo

Charcoal from probable hearth, Mound B, Pit 1, 100 to $120 \mathrm{~cm}$ depth.
$510+65$ A.D. 1440

$$
390 \pm 65
$$

A.D. 1560

Comment (H.B.N.) : Site is slightly younger than archaeological evidence in- 
dicates. If dates were corrected for the higher atmospheric $\mathrm{C}^{14}$ activity for this period that tree ring studies indicate, agreement would be excellent.

\section{South America}

\section{UCLA-664. Chilea, Peru}

$$
5370 \pm 120
$$

Cane from remains of semi-subterranean house at Chilca, $50 \mathrm{mi}$ S of Lima on $\mathrm{S}$ coast of Peru $\left(13^{\circ} \mathrm{S}\right.$ Lat, $77^{\circ} \mathrm{W}$ Long), Pit 105XVIC. House, belonging to a very early Peruvian culture, was in excellent state of preservation permitting detailed analysis of its construction. Associated with a complex of interlocking refuse mounds covering area of ca. 5 acres. Shell and ash form bulk of midden which has maximum depth of ca. 2 m. Comment (C.W.M.) : site will be reported by F. Enger who has obtained several other $\mathrm{C}^{1+}$ dates in same time range for this site. Coll. 1963 by C. Donnan; subm. by C. W. Meighan.

\section{Peat series, South Georgia Island}

Acid moncot and moss peats collected by members of British Antarctic Survey from walls of freshly dug pits in bogs of W Cumberland Bay area, South Georgia Island (54 $\mathrm{S}$ Lat, $37^{\circ} \mathrm{W}$ Long). Samples obtained during I.G.Y. Program, for microfossil and volcanic ash analyses and climate studies. Pollen fairly abundant. Samples (small) subm. by Lucy Cranwell, Tucson, Arizona.

\section{UCLA-658A. Jason Islet}

$4300 \pm 800$

Poa flabellata peat ca. $10 \mathrm{ft}$ below wholly organic layer well above rock rubble at $12 \mathrm{ft}$. Coll. 1961 by the late Jeremy Smith. Comment: age comparable with peat so far dated for Albatross Plain, Gough Island (Hafsten, $1960)$.

UCLA-658B. W of Grytviken, Profile 21

$6500 \pm 500$ 4550 в.C.

Moss and juncaceous peat from depth of 40 to 45 in. Coll. 1961 by S. W. Greene. Comment: gives evidence of local plant growth in Boreal-Atlantic transition period. Age comparisons may be made with Rio Negro series, Argentina (Y.196-Y.198, Yale IV).

\section{UCLA-658C. W of Grytviken, Profile $19 \quad 2500 \pm 800$}

Bottom sample from depth of 55 to 60 in. Coll. 1961 by S. W. Greene. Cimment: apparently (if the dating from this very small sample can be relied on) peat-formers with more rapid growth have built up this younger profile.

\section{E. Africa}

\section{UCLA-229. Twin Rivers, Northern Rhodesia $\quad 22,800 \pm 1000$}

Travertine from breccia-filled fissure, Twin Rivers, Northern Rhodesia $\left(15^{\circ} 31^{\prime} \mathrm{S}\right.$ Lat, $28^{\circ} 11^{\prime} \mathrm{E}$ Long). Fissures, 5 to $6 \mathrm{ft}$ in depth, occur on top of Twin Rivers Kopje and contain remains of Middle Stone Age industry and fauna. Travertine believed to have been formed as result of seepage of water 
down slopes of fissures during cooler and wetter climate of main part of last Pluvial. Travertine sample ca. 1 in. in thickness with thin brown layer through center. Bottom and top halves of sample therefore dated. Age of top layer was $23,700 \pm 1000 \mathrm{yr}$ and of bottom layer $21,900 \pm 1000 \mathrm{yr}$; thus it appears that $\mathrm{C}^{14}$ exchange subsequent to deposition has not been significant. Ages have been computed on basis of $73 \%$ of 0.95 NBS oxalic acid. Coll. 1956 and subm. by J. D. Clark, Anthropol. Dept., Univ. of California, Berkeley.

\section{UCLA-629. Tshangula Cave, Southern Rhodesia}

Charcoal from bottom of Wilton layer, Tshangula Cave, Southern Rhodesia $\left(20^{\circ} 25^{\prime} \mathrm{S}\right.$ Lat, $28^{\circ} 35^{\prime} \mathrm{E}$ Long), overlying consolidated ash containing the Early Wilton Culture of the Later Stone Age. Comment (J.D.C.) : result is older than expected in view of (unpublished) Gulbenkian Laboratory date of $9400 \pm 100$ for the same culture at Pomongwe Cave. Could be consistent, however, if sample came from the consolidated white ash floor and was covered by the ash of the later occupation. Coll. by C. K. Cooke; subm. by J. D. Clark.

\section{F. Pacific Ocean}

\section{Palawan Island series, Philippines}

Charcoal from Tabon Cave and Duyong Cave, Quezon municipality, W coast of Palawan Island, Philippines ( $9^{\circ} 20^{\prime} \mathrm{N}$ Lat, $117^{\circ} 45^{\prime} \mathrm{E}$ Long). The first collections in the Philippines by Beyer and others (Beyer, 1947) of crude stone tools similar to types found in Indonesia and neighboring countries in Asia, and the discovery of fossils of extinct Pleistocene mammals, strongly suggested that man is of great antiquity in the Philippines. However, knowledge concerning early man in the Islands has been built almost entirely upon artifacts recovered on the surface of ground, as sites where controlled archaeological investigations are possible are extremely rare. Thus the discovery in 1962 of 40 caves, on the W coast of Palawan Island, which contained fossil human and animal bones in association with an industry of flake tools of chert, prompted extensive excavations in 1962-63. Tabon Cave provided an extremely attractive site for habitation because of its size, the main chamber being $18 \mathrm{~m}$ by $40 \mathrm{~m}$. Also, the great size of the mouth of the cave provided a large, well-lighted and airy chamber. Tabon Cave has not been completely excavated; a much deeper and older flake-tool industry has recently been uncovered but no organic materials have been found with it. On the other hand, Duyong Cave is a small cave and has been completely excavated.

UCLA-285. Tabon Cave, $50 \mathrm{~cm}$ depth

Charcoal from the most recent flake-tool industry layer, No. 1, in Tabon Cave, $50 \mathrm{~cm}$ depth, Mus. No. 2072. Associated with fossil human and animal bones. Coll. 1962 and subm. by R. B. Fox, Natl. Mus., Manila, Philippines.

\section{UCLA-284. Tabon Cave, $56 \mathrm{~cm}$ depth}

Charcoal from same layer as UCLA-285, $56 \mathrm{~m}$ depth, Mus. No. 9060. Coll. 1962 and subm. by R. B. Fox. 
UCLA-283. Tabon Cave, 141 to $151 \mathrm{~cm}$ depth

Charcoal from flake-tool industry layer No. 2, Tabon Cave, 141 to $151 \mathrm{~cm}$ depth, Mus. No. 2170. Coll. 1962 and subm. by R. B. Fox.

UCLA-288. Tabon Cave, $147 \mathrm{~cm}$ depth

Charcoal from flake-tool industry layer No. 3, Tabon Cave, $147 \mathrm{~cm}$ depth, Mus. No. 4001. Coll. 1962 and subm. by R. B. Fox.

\section{UCLA-287. Duyong Cave, $48 \mathrm{~cm}$ depth}

$4630 \pm 250$

\section{0 в.c.}

Neolithic burial which is overlain by Chalcolithic Jar burial. Associated with intrusive from upper burial. Coll. 1962 and subm. by R. B. Fox and A. Evangelista.

\section{UCLA-286. Duyong Cave, 62 to $68 \mathrm{~cm}$ depth}

$7000 \pm 250$

5050 в.с.

Charcoal from a flake-tool industry layer, 62 to $68 \mathrm{~cm}$ depth, Duyong Cave, Mus. No. 533 and 611. Associated with a midden layer of shells below a late Neolithic burial. Coll. 1962 and subm. by R. B. Fox and A. Evangelista. Comment: sample size was in general very small; hence it is hoped that further excavations will yield larger samples so that actual ages could be assigned to UCLA-283, 285, 288. Of the many possible causes of the stratigraphic discrepancy between UCLA-284 and 285, the most likely is the egg-laying activities of the tabon or megapode bird which have mixed up artifacts that vary considerably in age. Three "infinite" dates, however, clearly establish considerable antiquity of flake-tool industry. This age is supported by the complete absence of shells from these layers, presumably because during a glacial period the shore line would have been 20 to $30 \mathrm{~km}$ from Tabon Cave, too remote for shellfish to be regularly utilized (Fox, 1963).

\section{UCLA-279. Mitaka City, Japan}

$4570 \pm 150$

Charcoal from under pile of large pebbles, in community site, Mitaka City, Tokyo, Japan $\left(35^{\circ} 41^{\prime} 16^{\prime \prime}\right.$ N Lat, $139^{\circ} 31^{\prime} 36^{\prime \prime}$ E Long). Sample in humus layer, $75 \mathrm{~cm}$ depth, associated with Atamadai and Katsusaka types of pottery of early half of Middle Jomon period. Expected age 4800 yr. Coll. 1962 by J. E. Kidder, Jr; subm. by G. C. Kennedy.

\section{G. England}

\section{Medieval English Carpentry series, England}

The three most important timbers of a timber-frame building are the post, the tiebeam and the top-plate. Differences in the actual order of assembly of these three timbers and of the joints used have been investigated (Hewett, 1961) for they should correlate with historical evidence as to age of structure. Coll. and subm. by C. A. Hewett, Coggeshall, Essex, England.

\section{UCLA-646. Barley-barn, Cressing Temple}

$$
\begin{array}{r}
940 \\
\text { A.D. } 1010
\end{array}
$$

Oak from principal post, SW corner of Barley-barn, Cressing Temple, Witham, Essex $\left(51^{\circ} 50^{\prime} \mathrm{N}\right.$ Lat, $0^{\circ} 36^{\prime} \mathrm{E}$ Long). This Barley-barn believed 
built by Knights Templar, on land granted them by Queen Maud in A.D. 1150. The joints used in construction are of a type that is extremely rare in England and was obsolete in France by A.D. 1225.

\section{UCLA-272. Barley-barn, Cressing Temple}

Oak from post-plate, E side of Barley-barn, Cressing Temple. Comment: re-examination of the building has shown that UCLA-272 was cut from an inserted timber and dates the second major reconstruction of the barn.

UCLA-273. Navestock Church, Essex

$770 \pm 60$

Wood from "notched-lap-joint," Navestock Church, Essex $\left(51^{\circ} 40^{\prime} \mathrm{N}\right.$ Lat, $0^{\circ} 13^{\prime}$ E Long). This type of joint was obsolete in France by A.D. 1260.

UCLA-274. Belehamp St. Paul's, Essex

$540 \pm 60$

A.D. 1410

Oak from tiebeam of barn at the Hall, Belchamp St. Paul's, North Essex $\left(52^{\circ} 4^{\prime} \mathrm{N}\right.$ Lat, $0^{\circ} 38^{\prime} \mathrm{E}$ Long). This tiebeam believed to be one cited in a lease of A.D. 1120.

\section{UCLA-645. Belchamp St. Paul's, Essex}

$600 \pm 70$

Wood from one of the posts on which tiebeam (UCLA-274) rests. Comment: together with UCLA-274, confirms that transverse frame is of uniform date and younger than expected.

Date lists:

REFERENCES

$\begin{array}{ll}\text { Chicago II } & \text { Libby, 1951 } \\ \text { Chicago III } & \text { Libby, 1952 } \\ \text { Chicago V } & \text { Libby, 1954 } \\ \text { La Jolla II } & \text { Hubbs, Bien and Suess, 1962 } \\ \text { Lamont IV } & \text { Broecker and Kulp, 1957 } \\ \text { Lamont VII } & \text { Olson and Broeker, 1961 } \\ \text { Michigan III } & \text { Crane and Griffin, 1958 } \\ \text { UCLA I } & \text { Fergusson and Libby, 1962 } \\ \text { UCLA II } & \text { Fergusson and Libby, 1963 } \\ \text { Yale IV } & \text { Deevey, Gralenski and Hoffren, 1959 }\end{array}$

Beyer, H. O., 1947, Outline review of Philippine archaeology by islands and provinces: Philippine Jour. Sci., v. 77, nos. 3-4, July-August.

Broecker, W. S., and Kulp, J. L., 1957, Lamont natural radiocarbon measurements IV: Science, v. 126, p. 1324-1334.

Broecker, W. S., and Walton, A., 1959, The geochemistry of $\mathrm{C}^{14}$ in fresh water systems: Geochim. et Cosmochim. Acta 16, p. 15.

Cheney, Ralph and Mason, Herbert L., 1934, A Pleistocene flora from the asphalt deposits at Carpinteria, Calif., Carnegie Inst. Washington Pub. no. 415-II, p. 45-79.

Crane, H. R., and Griffin, J. B., 1958, University of Michigan radiocarbon dates III: Science, v. 128 , p. $1117-123$.

Davis, J. T., 1960, The archaeology of the Fernandez site, a San Francisco Bay Region shellmound: Univ. of Calif. Archaeol. Survey, report no. 49, paper no. 75, p. 11-52.

Deevey, E. S., Gralenski, L. J., and Hoffren, V., 1959, Yale natural radiocarbon measurements IV: Am. Jour. Sci. Radioc. Supp., v. 1, p. 144-172.

Fergusson, G. J., and Libby, W. F., 1962, UCLA radiocarbon dates I: Radiocarbon, v. 4, p. $109-114$

1963, UCLA radiocarbon dates II : Radiocarbon, v. 5, p. 1-22

Fox, R. B., 1963, Progress report, ancient man in Palawan: Natl. Mus., Manila, Philippines.

Godwin, H., 1962, Half-life of radiocarbon: Nature, v. 195, p. 984. 
Hafsten, Ulf, 1960, Pleistocene development of vegetation and climate in Tristan da Cunha and Gough Island: Arb. f. Univ. Bergen, Mat.-Naturv. ser., v. 20, p. 1-48.

Harrington, M. R., and Simpson, R. D., 1961, Tule Springs, Nevada, with other evidences of Pleistocene may in North America: Southwest Mus. Papers, no. 18, 146 p., charts, maps.

Heizer, R. F., 1951, Preliminary report on the Leonard Rockshelter site, Pershing County, Nevada: Am. Antiquity, v. 17, p. 89-98.

1958, Radiocarbon dates from California of archaeological interest: Univ. of Calif. Archaeol. Survey, report no. 44, p. 1-16.

Heizer, R. F., and Bennyhoff, J. A., 1958, Archaeological investigation of Cuicuilco, Valley of Mexico, 1957: Science, v. 127, p. 232-233.

1961, The archaeology of two sites at Eastgate, Churchill County, Nevada: I, Wagon Jack Shelter: Univ. of Calif. Anthropol. Records, v. 20, no. 4, p. 119-138.

Hewett, C. A., 1961, Timber-building in Essex: Trans. Ancient Monuments Soc., v. 9, new series, p. 33-56.

Hubbs, C. L., Bien, G. S., and Suess, H. E., 1962, La Jolla natural radiocarbon measurements II: Radiocarbon, v. 4, p. 204-238.

King, C. D., 1962, Excavations at Parker Mesa (LAn-215): Annual report for 1961-62, Archaeol. Survey, UCLA, p. 91-155.

Libby, W. F., 1951, Radiocarbon dates II: Science, v. 114, p. 291-296.

1952, Chicago radiocarbon dates III: Science, v. 116, p. 673-681.

1954, Chicago radiocarbon dates V: Science, v. 120, p. 739.

Olson, E. A., and Broecker, WV. S., 1961, Lamont natural radiocarbon measurements VII : Radiocarbon, v. 3, p. 141-175.

Treganza and Bierman, 1958, The Topanga culture: final report on excavations, 1948 : Univ. of Calif. Anthropol. Records, v. 12, no. 2.

Wells, P. V., and Jorgensen, C. D., 1964, Pleistocene wood rat middens and climatic change in Mohave Desert: a record of juniper woodlands: Science, v. 143, p. 1171-1173. 